\title{
Identifikasi faktor Penerapan Green Supply Chain Management Pada Industri Furniture Kayu
}

\author{
Much. Djunaidi*, M. Abdul Azis Sholeh, Nur Muhammad Mufiid \\ Jurusan Teknik Industri, Universitas Muhammadiyah Surakarta \\ Jalan Ahmad Yani, Pabelan, Kartasura, Surakarta 57162 Telp. 0271-717417 \\ *Korespondensi penulis, surel: much.djunaidi@ums.ac.id
}

\begin{abstract}
Competition in the manufacturing industry continues to increase, along with the shift in consumer demands increasingly aware of environmental sustainability. Implementation of green supply chain management became one of the company's attention to answer the demands. The government has also regulated related regulations. In Indonesia, wood furniture industries related to environmental conservation have not applied Green Supply Chain Management (GSCM). This study examines the factors that encourage the implementation of GSCM in the wood furniture industry, by involving relevant stakeholders. The weight of the influencing factor is determined by the Analytical Hierarchy Process (AHP) method. The results show consumer behavior, support from top management, and organizational strategies that influence the application of GSCM predominantly.
\end{abstract}

Keywords: GSCM, wooden furniture, AHP, customer requirement, strategy.

\begin{abstract}
Abstrak
Persaingan industri manufaktur terus meningkat, seiring dengan pergeseran tuntutan konsumen yang semakin sadar dengan kelestarian lingkungan. Penerapan green supply chain management menjadi salah satu bentuk perhatian perusahaan untuk menjawab tuntutan tersebut. Pemerintah juga telah mengatur regulasi terkait. Di Indonesia, industri furniture kayu yang terkait pelestarian lingkungan belum banyak menerapkan Green Supply Chain Management (GSCM). Penelitian ini mengkaji faktor-faktor yang mendorong penerapan GSCM pada industri furniture kayu, dengan melibatkan stakeholder terkait. Bobot faktor yang berpengaruh ditentukan dengan metode Analytical Hierarchy Process (AHP). Hasil penelitian menunjukkan perilaku konsumen, dukungan dari manajemen puncak, dan strategi organisasi yang memengaruhi penerapan GSCM secara dominan.
\end{abstract}

Kata kunci: GSCM, furniture kayu, AHP, tuntutan konsumen, strategi.

\section{Pendahuluan}

Industri furnitur kayu memiliki peran penting dalam perekonomian Indonesia, karena industri ini mempunyai potensi besar untuk perdagangan domestik dan juga perdagangan internasional. Di pasar global, Indonesia merupakan salah satu eksportir furnitur terbesar di dunia, bersama dengan China, Italia, Vietnam dan Malaysia. Tidak diragukan lagi, industri ini diakui memiliki peran penting lainnya di Indonesia sebagai sumber devisa. Industri mebel kayu di Indonesia dicirikan sebagai industri padat karya sekaligus padat karya. Industri ini mempekerjakan sekitar dua juta orang secara langsung, dan delapan juta pekerja tambahan secara tidak langsung [1]. Saat ini, industri furnitur kayu di Indonesia harus menghadapi persaingan ketat terutama dari negara-negara Asia seperti China, Malaysia dan Vietnam, memasuki pasar global [2]. Tantangan industri bertambah dengan berkembangnya kesadaran konsumen terhadap isu-isu lingkungan yang menuntut perusahaan untuk menerapkan peraturan yang 
ramah lingkungan, seperti eco-labelling, SFI (Sustainable Forestry Initiative) dan FSC (Forest Steward Council) yang telah diterapkan oleh Uni Eropa [3].

Standar eco-labelling diterapkan dengan 3 jenis sertifikat, yaitu SFM (Sustainable Forest Management), VLO (Verification of Legal Origin) dan CoC (Chain of Custody). Di Indonesia, perusahaan manufaktur yang menggunakan kayu sebagai bahan baku, perlu memiliki sertifikat yang dikeluarkan dalam bentuk Sistem Pengelolaan Hutan Produksi Lestari (SPHPL), Sistem Verifikasi Legalitas Kayu (SVLK) dan Sistem Lacak Balak (SLB). Tantangannya adalah lama waktu proses pengurusan sertifikat yang mencapai 4 sampai 6 bulan dan biaya pengurusan yang mencapai $10 \%$ dari biaya produksi [4]. Penerapan berbagai regulasi yang berkaitan dengan aspek lingkungan pada industri manufaktur merupakan bentuk implementasi dari manajemen rantai pasok berwawasan lingkungan (green supply chain management). Perusahaan juga perlu meninjau sistem perancangan dan pengembangan produk, proses manufaktur, sistem distribusi produk, dan proses daur ulang (recycle) atau pengakhiran (end of life) dari produk yang dibuat. Perusahaan furniture kayu menghadapi tantangan untuk memenuhi peningkatan tuntutan konsumen yang terkait dengan isu-isu lingkungan. Beberapa perusahaan yang berorientasi ekspor berupaya memenuhi tuntutan pengelolaan berkelanjutan, karena ada tuntutan dari regulasi perdagangan global. Perusahaan yang berorientasi pasar dalam negeri seharusnya juga memiliki kesadaran juga untuk menerapkan green supply chain management.

Istilah manajemen rantai pasok (supply chain management) memasuki ranah publik pertama kali, ketika Keith Oliver, seorang konsultan di Booz Allen Hamilton, menggunakannya dalam sebuah wawancara untuk Financial Times pada tahun 1982. Pada saat itu, istilah tersebut tidak banyak digunakan dan juga tidak ada di dalam kamus. Istilah rantai pasok baru banyak dikenal pada pertengahan 1990-an, yaitu ketika banyak artikel dan buku yang diterbitkan dengan membahas subyek tersebut. Pada akhir 1990-an, istilah manajemen rantai pasok menjadi kata kunci manajemen, di mana manajer operasi mulai menggunakannya dalam judul laporan dan meningkat secara teratur $[5,6]$. Beberapa peneliti telah memberikan definisi manajemen rantai pasok dalam artikel ilmiah yang ditulis. Mentzer, et al. [7] menyatakan bahwa manajemen rantai pasok adalah koordinasi strategis dan sistematis dari fungsi bisnis tradisional dan taktik di dalam seluruh fungsi bisnis (baik di dalam perusahaan dan seluruh bisnis dalam rantai pasok), untuk meningkatkan kinerja jangka panjang dari masing-masing perusahaan dan rantai pasok secara keseluruhan. Lambert [8] menyatakan bahwa manajemen rantai pasokan adalah integrasi proses bisnis utama di seluruh rantai pasokan untuk menciptakan nilai bagi pelanggan dan pemangku kepentingan. Dengan fokus pada pelanggan, strategi rantai pasok memerlukan keterkaitan total dalam rantai pasok yang bekerja sama secara efisien untuk menciptakan kepuasan pelanggan pada titik akhir pengiriman ke konsumen [9]. Sebagai konsekuensinya, biaya harus diturunkan ke seluruh rantai dengan mengeluarkan biaya yang tidak perlu dan memusatkan perhatian pada penambahan nilai. Efisiensi keseluruhan harus ditingkatkan, hambatan dikeluarkan dan pengukuran kinerja harus berfokus pada efisiensi sistem total dan pembagian penghargaan yang adil kepada mereka yang memiliki nilai tambah rantai pasokan. Sistem rantai pasokan harus responsif terhadap permintaan pelanggan.

Green Supply Chain Management (GSCM) merupakan sebuah upaya untuk memasukkan isu-isu lingkungan dalam konteks manajemen rantai pasok [10]. GSCM melibatkan secara keseluruhan rantai pasok mulai dari pemasok, perusahaan manufaktur, konsumen, dan juga logistik umpan balik (reverse logistic) di dalam sebuah rantai pasok lingkar tertutup (closed-loop supply chain) [11]. GSCM merupakan salah 
satu model pengelolaan lingkungan pada perusahaan yang telah banyak diadopsi pada perusahaan manufaktur. Hal tersebut dimaksudkan untuk mengurangi atau meminimalkan pengaruh negatif pada lingkungan. Konsep GSCM adalah mengintegrasikan pengelolaan rantai pasok dengan pemikiran penyelamatan lingkungan, yang meliputi proses perancangan dan pengembangan produk, seleksi pemasok dan proses pengadaan (procurement), proses manufaktur dengan teknologi bersih, distribusi produk akhir kepada konsumen, sampai dengan daur ulang (recycle) pada masa akhir hidup produk [12]. Berbagai jenis industri manufaktur telah mengimplementasikan GSCM sebagai strategi pengembangan perusahaan untuk memenuhi tuntutan konsumen terhadap isu-isu lingkungan. Ninlawan, et al. [13] menggambarkan implementasi GSCM pada industri elektronika. Pengukuran kinerja manajemen yang menerapkan GSCM pada industri otomotif yang mengalami kondisi tidak menentu (uncertainty) karena adanya perubahan tuntutan konsumen. Perubahan tuntutan konsumen ini setidaknya dapat dilihat pada pasar di negara China dan Asia pada umumnya [14].

Pengukuran kinerja manajemen dalam menerapkan sistem rantai pasok berkelanjutan menjadi kajian yang cukup penting. Hadiguna, et al. [15] mengembangkan model pendukung keputusan untuk mengukur kinerja manajemen perusahaan yang berbasis pada metode Delphi dan metode Analytical Herarchy Process (AHP) dalam penyusunan criteria dan penentuan bobot kriterianya. Model pendukung keputusan ini kemudian dikembangkan menjadi sistem informasi manajemen untuk rantai pasok berkelanjutan yang berbasis pada pengetahuan (knowledge based information systems) [16]. AHP merupakan suatu model pendukung keputusan yang dikembangkan oleh Saaty [17]. Model pendukung keputusan ini menguraikan masalah multi-faktor atau multi-kriteria yang kompleks menjadi suatu hirarki. Hirarki didefinisikan sebagai suatu representasi dari sebuah permasalahan yang kompleks dalam suatu struktur multi level di mana level pertama adalah tujuan, yang diikuti level faktor, kriteria, sub kriteria, dan seterusnya ke bawah hingga level terakhir dari alternative [17]. Dengan hirarki, suatu masalah yang kompleks dapat diuraikan ke dalam kelompok-kelompok yang diatur menjadi suatu bentuk hirarki sehingga permasalahan tampak lebih terstruktur dan sistematis.

Beberapa penelitian telah banyak dilakukan sebelumnya mengenai implementasi GSCM, antara lain: (1) melakukan perancangan model pengukuran kinerja green supply chain pada industri pulp dan kertas [18], (2) yang melakukan analisis finansial penerapan konsep GSCM pada pengolahan kopi [19], (3) mengkaji penerapan GSCM pada industri elektronika [13], (4) melakukan pengukuran kinerja manajemen pada perusahaan otomotif yang telah menerapkan GSCM [14]. Namun penelitian tentang identifikasi faktor yang memengaruhi perusahaan dalam menerapkan GSCM pada industri manufaktur belum pernah dilakukan. Artikel ini bertujuan untuk melakukan identifikasi faktor yang memengaruhi perusahaan dalam menerapkan GSCM, dan menentukan bobot dari masing-masing faktor dalam memengaruhi perusahaan untuk menerapkan GSCM, khususnya pada perusahaan furniture berbahan kayu.

\section{Metode Penelitian}

Pada tahap awal, telah dilakukan penelusuran literatur untuk mengidentifikasi faktor-faktor yang memengaruhi penerapan GSCM. Artikel ilmiah yang ditelusuri memuat faktor yang memengaruhi keberhasilan penerapan GSCM pada berbagai sektor industri. Selanjutnya membuat struktur hirarki permasalahan yang mendorong implementasi GSCM pada industri furniture. Struktur hirarki permasalahan dilakukan 
berdasarkan penelusuran referensi yang memberikan informasi mengenai best practice dalam penerapan GSCM.

Penelitian ini dilakukan dengan melibatkan responden memiliki kapasitas atau kepakaran dalam penerapan GSCM pada industri pengolahan kayu, khususnya furniture. Focus Group Discussion dilakukan untuk verifikasi struktur hirarki masalah yang telah dihasilkan. Jumlah responden sebanyak 10 responden. Responden mewakili 3 pihak yang dinilai memiliki pengaruh dalam pengambilan keputusan publik, yaitu dengan komposisi 3 orang dari akademisi (academic), 4 orang dari pengusaha (business), dan 3 orang dari pemerintah (government).

Hasil penelusuran faktor digunakan untuk menyusun kuesioner perbandingan berpasangan, dengan mengikuti metode AHP yang telah diusulkan oleh Saaty [17]. Metode AHP digunakan untuk menghitung bobot pengaruh tiap faktor dalam penerapan GSCM di industri furniture. Responden memberikan penilaian perbandingan berpasangan secara terpisah dan tidak saling memengaruhi. Perhitungan AHP menggunakan software Microsoft Excel.

\section{Hasil dan Pembahasan}

Penelusuran referensi telah dilakukan untuk menentukan faktor-faktor yang mendorong diterapkannya GSCM. Tabel 1 menjadi rangkuman dari beberapa referensi yang digunakan untuk menentukan faktor-faktor yang memengaruhi perusahaan untuk menerapkan GSCM.

Tabel 1 Faktor yang memengaruhi penerapan Green Supply Chain Management (GSCM)

\begin{tabular}{|c|c|c|c|c|c|c|}
\hline No & Kriteria & Ref. [14] & Ref. [20] & Ref. [21] & Ref [22] & $\operatorname{Ref}[11]$ \\
\hline 1 & $\begin{array}{l}\text { Dukungan top manajemen } \\
\text { (Support from top } \\
\text { management) }\end{array}$ & $\checkmark$ & $\checkmark$ & $\checkmark$ & & $\checkmark$ \\
\hline 2 & $\begin{array}{l}\text { Strategi organisasi } \\
\text { (Organization strategy) }\end{array}$ & $\checkmark$ & $\checkmark$ & $\checkmark$ & $\checkmark$ & $\checkmark$ \\
\hline 3 & $\begin{array}{l}\text { Pengurangan biaya } \\
\text { (Cost reduction) }\end{array}$ & $\checkmark$ & & $\checkmark$ & & \\
\hline 4 & $\begin{array}{l}\text { Keuntungan ekonomis } \\
\text { (Economic benefit) }\end{array}$ & $\checkmark$ & $\checkmark$ & & & $\checkmark$ \\
\hline 5 & $\begin{array}{l}\text { Logistik berbalik } \\
\text { (Reverse logistics) }\end{array}$ & $\checkmark$ & & $\checkmark$ & $\checkmark$ & \\
\hline 6 & $\begin{array}{l}\text { Perilaku pemasok } \\
\text { (Suppliers behavior) }\end{array}$ & $\checkmark$ & & $\checkmark$ & & \\
\hline 7 & $\begin{array}{l}\text { Peraturan perundang- } \\
\text { undangan (Regulatory) }\end{array}$ & $\checkmark$ & $\checkmark$ & & $\checkmark$ & $\checkmark$ \\
\hline 8 & $\begin{array}{l}\text { Perilaku konsumen } \\
\text { (Market/Consumer) }\end{array}$ & $\checkmark$ & $\checkmark$ & $\checkmark$ & $\checkmark$ & \\
\hline 9 & $\begin{array}{l}\text { Kondisi pesaing } \\
\text { (Competitors condition) }\end{array}$ & $\checkmark$ & & $\checkmark$ & $\checkmark$ & $\checkmark$ \\
\hline 10 & $\begin{array}{l}\text { Tuntutan masyarakat } \\
\text { (Social/Stakeholder) }\end{array}$ & $\checkmark$ & & $\checkmark$ & $\checkmark$ & \\
\hline
\end{tabular}


Tabel 1 menunjukkan terdapat 10 (sepuluh) faktor yang mendorong penerapan GSCM, meliputi: (a) Dukungan top manajemen (support from top management), (b) Strategi organisasi (organization strategy), (c) Pengurangan biaya (cost reduction), (d) Keuntungan ekonomis (economic benefit), dan (e) Logistik berbalik (reverse logistics), (f) Perilaku pemasok (suppliers), (g) Perundang-undangan (regulatory), (h) Perilaku konsumen (market/ consumer), (i) Pesaing (competitors), dan (j) Tuntutan masyarakat (social/stakeholder).

Struktur hirarki permasalahan dalam penelitian ini dapat dilihat pada Gambar 1. Manajemen puncak merupakan pengambil keputusan yang tertinggi dalam kebijakan yang dilaksanakan oleh perusahaan. Hal-hal yang penting dan strategis terhadap perkembangan perusahaan ditangani langsung oleh manajemen puncak. Kinerja manajemen dalam melakukan menjalin komunikasi dan berkolaborasi dengan pemasok dipengaruhi oleh keputusan dan dukungan yang diberikan oleh manajemen puncak [23]. Komitmen manajemen puncak juga memberikan dampak yang berpengaruh dalam pengelolaan kualitas produk dan proses [24]. Secara umum, dukungan manajemen puncak dalam pelaksanaan organisasi perusahaan akan memberikan pengaruh terhadap perbaikan kinerja perusahaan [25].

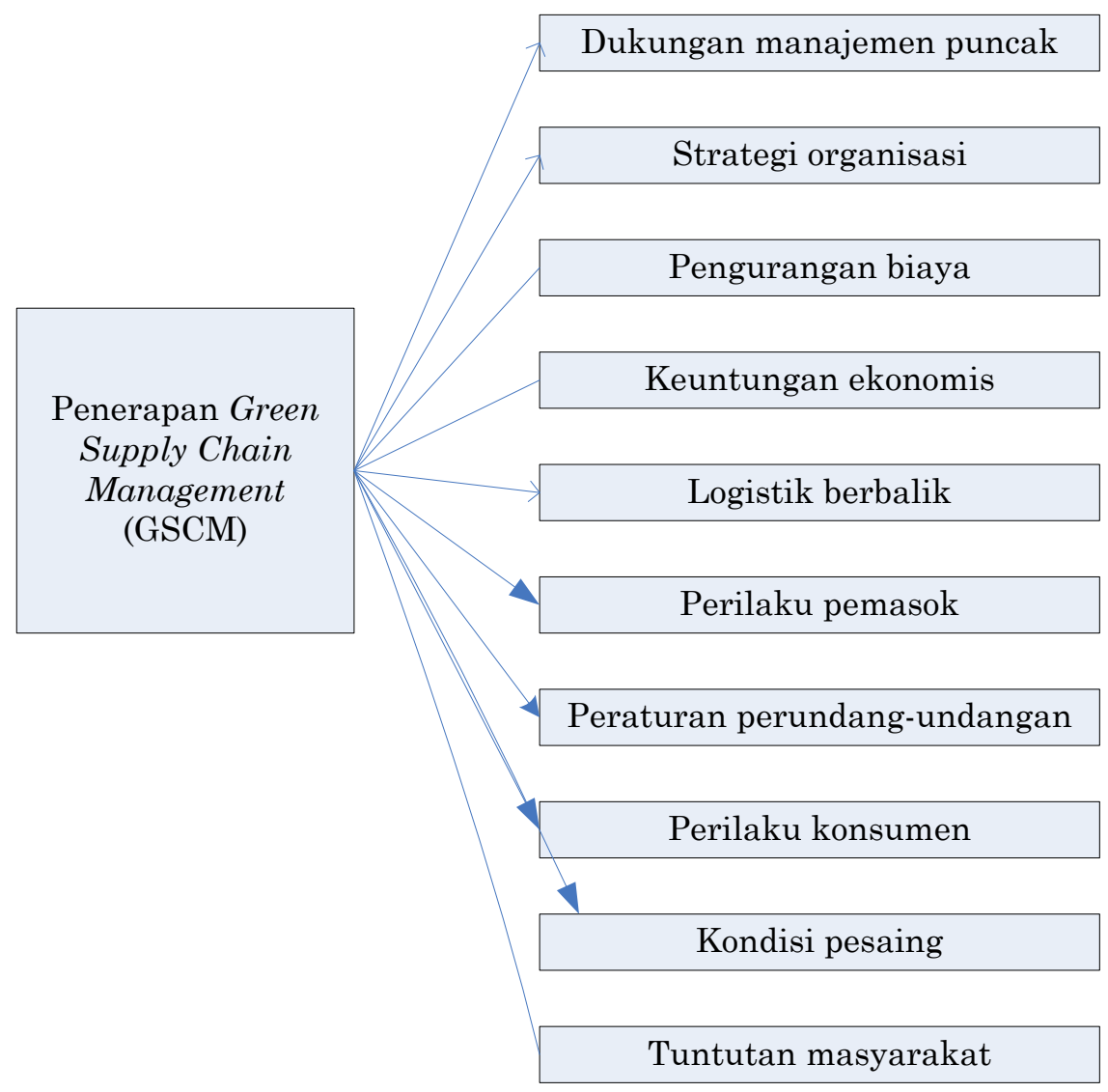

Level 0: Tujuan Permasalahan $\quad$ Level 1: Bobot faktor

Gambar 1 Struktur hirarki permasalahan dalam penelitian ini. 
Strategi perusahaan untuk menerapkan GSCM dalam operasional usaha perusahaan menjadi hal penting dalam era persaingan yang ketat dan munculnya kesadaran konsumen akan pentingnya kelestarian lingkungan. Perusahaan dituntut untuk menerapkan strategi yang mendukung kelestarian lingkungan, atau biasa diistilahkan dengan green strategy [26]. Dalam kajian yang telah dilakukan, penerapan GSCM dapat memberikan keuntungan kompetitif (competitive advantages) yang menarik bagi perusahaan [27]. Deif [28] telah menggambarkan peta persaingan perusahaan dengan menerapkan strategi produksi hijau (green production) dengan menggunakan pendekatan sistem dinamis.

GSCM dalam banyak hal diselaraskan dengan lean manufacturing, dimana aktivitas yang tidak memberikan nilai tambah akan dihilangkan. Aktivitas yang harus dilakukan hanya pada aktivitas yang memberikan nilai tambah atau aktivitas yang perlu dilakukan. Aktivitas yang tidak diperlukan dan tidak memberikan nilai tambah akan dieliminasi. Efisiensi ekonomi aktivitas ini dapat memangkas biaya produksi secara keseluruhan [29].

Selain pemangkasan biaya produksi, penerapan GSCM juga memberikan keuntungan ekonomis bagi perusahaan. Isu terkait kelestarian lingkungan memberikan sentiment yang positif bagi konsumen dalam menentukan pilihan produk yang akan digunakan [30]. Perspektif sosial dalam keberpihakan pada isu kelestarian lingkungan memberikan dampak yang positif pada sisi ekonomis [31, 32].

Alur pasokan juga memengaruhi keberhasilan pelaksanaan GSCM oleh perusahaan. Keterkaitan dan komitmen dengan pemasok menjadi penting untuk mendapat perhatian. Perilaku pemasok yang konsisten akan mendukung perusahaan dalam untuk turut konsisten dalam pelaksanaan GSCM [33]. Untuk mendapatkan jaminan pasokan yang memenuhi ketentuan GSCM, beberapa perusahaan menerapkan logistik berbalik (reverse logistics) dengan mengolah kembali produk yang telah selesai atau habis fungsi gunanya [34].

Faktor lain yang turut memengaruhi penerapan GSCM adalah peraturan perundangan. Otoritas pemerintah dapat memberikan insentif yang mendorong perusahaan untuk menerapkan GSCM [35].

Tabel 2 Matriks perbandingan berpasangan

\begin{tabular}{ccccccccccc}
\hline & $\mathrm{A}$ & $\mathrm{B}$ & $\mathrm{C}$ & $\mathrm{D}$ & $\mathrm{E}$ & $\mathrm{F}$ & $\mathrm{G}$ & $\mathrm{H}$ & $\mathrm{I}$ & $\mathrm{J}$ \\
\hline $\mathrm{A}$ & 1,0000 & 1,6324 & 1,7904 & 0,8748 & 2,2998 & 1,8411 & 0,7760 & 0,7760 & 1,9259 & 4,1718 \\
$\mathrm{~B}$ & 0,6126 & 1,0000 & 2,3301 & 2,0820 & 3,0313 & 1,7888 & 2,3821 & 0,4399 & 1,3787 & 1,0840 \\
$\mathrm{C}$ & 0,5585 & 0,4292 & 1,0000 & 0,5192 & 1,6295 & 1,0283 & 0,9016 & 0,8434 & 1,3323 & 1,2453 \\
$\mathrm{D}$ & 1,1431 & 0,4803 & 1,9259 & 1,0000 & 2,0119 & 1,2335 & 0,5944 & 0,7101 & 1,2668 & 1,0339 \\
$\mathrm{E}$ & 0,4348 & 0,3299 & 0,6137 & 0,4971 & 1,0000 & 0,9521 & 0,4325 & 0,5677 & 0,5962 & 1,5613 \\
$\mathrm{~F}$ & 0,5432 & 0,5590 & 0,9725 & 0,8107 & 1,0503 & 1,0000 & 0,7388 & 0,6156 & 1,0757 & 1,8485 \\
$\mathrm{G}$ & 1,2887 & 0,4198 & 1,1092 & 1,6824 & 2,3123 & 1,3535 & 1,0000 & 0,7034 & 0,7834 & 2,9891 \\
$\mathrm{H}$ & 1,2887 & 2,2731 & 1,1856 & 1,4082 & 1,7616 & 1,6244 & 1,4216 & 1,0000 & 1,7600 & 2,4134 \\
$\mathrm{I}$ & 0,5192 & 0,7253 & 0,7506 & 0,7894 & 1,6772 & 0,9296 & 1,2765 & 0,5682 & 1,0000 & 1,8057 \\
$\mathrm{~J}$ & 0,2397 & 0,9225 & 0,8030 & 0,9672 & 0,6405 & 0,5410 & 0,3345 & 0,4144 & 0,5538 & 1,0000 \\
\hline
\end{tabular}

Penilaian perbandingan tingkat kepentingan antar faktor (Tabel 2 ) telah dilakukan oleh responden yang telah ditentukan. Responden dengan sudut pandang dan pengalaman masing-masing memberikan penilaian tersebut, sehingga memungkinkan 
terjadinya perbedaan penilaian antar responden. Konsolidasi penilaian responden dilakukan dengan menentukan nilai rata-rata geometri (geometric means) dari penilaian responden sesuai yang diusulkan oleh Saaty [17]. Tabel 2 menunjukkan hasil nilai ratarata geometri yang kemudian digunakan untuk menghitung bobot faktor sesuai dengan pendekatan analytical hierarchy process (AHP).

Tabel 3 Hasil perhitungan bobot kriteria

\begin{tabular}{clcc}
\hline No & \multicolumn{1}{c}{ Kriteria } & Bobot & Ranking \\
\hline A & Dukungan manajemen puncak & 0,1403 & 2 \\
B & Strategi organisasi & 0,1379 & 3 \\
C & Pengurangan biaya & 0,0826 & 7 \\
D & Keuntungan ekonomis & 0,0999 & 5 \\
E & Reverse logistik & 0,0587 & 9 \\
F & Perilaku pemasok & 0,0787 & 8 \\
G & Peraturan perundangan & 0,1137 & 4 \\
H & Perilaku konsumen & 0,1460 & 1 \\
I & Kondisi pesaing & 0,0852 & 6 \\
J & Tuntutan masyarakat & 0,0569 & 10 \\
\hline & & 1,0000 & \\
\hline & $\lambda$ & & \\
& Consistency Index $(\mathrm{CI})=0,059749$ & & \\
& Random Index $(\mathrm{n}=10)=1,49$ & & \\
& Consistency Ratio $(\mathrm{CR})=0,0401$ & &
\end{tabular}

Perhitungan nilai bobot kriteria dilakukan dengan menggunakan software Microsoft Excel. Selain nilai bobot kriteria, juga dilakukan perhitungan nilai indeks konsistensi (consistency index) dan nilai rasio konsistensi (consistency ratio). Indeks konsistensi merupakan konsistensi responden dalam memberikan nilai perbandingan berpasangan. Rasio konsistensi merupakan konsistensi dari struktur hirarki permasalahan. Tabel 3 menunjukkan hasil perhitungan bobot kriteria dan nilai konsistensi permasalahan.

Dengan memperhatian nilai Consistency Index (CI) dan Consistency Ratio (CR) yang ada pada Tabel 3, maka didapatkan bahwa nilai CI dan nilai CR adalah kurang dari $10 \%$ atau 0,1 . Hal ini menunjukkan bahwa penilaian responden terhadap kasus yang diamati telah konsisten dan struktur hirarki permasalahan yang disusun juga telah memenuhi syarat konsistensi.

Berdasarkan hasil perhitungan AHP, yang ditampilkan pada Tabel 3, perilaku konsumen memiliki pengaruh paling besar bagi perusahaan untuk menerapkan GSCM. Faktor kedua adalah dukungan manajemen puncak (top management). Faktor ketiga adalah strategi organisasi. Secara berurutan, faktor-faktor berikutnya adalah faktor peraturan perundang-undangan, keuntungan ekonomis, kondisi pesaing, pengurangan biaya, perilaku pemasok, reverse logistic, dan terakhir tuntutan masyarakat.

\section{Simpulan}

Green supply chain management (GSCM) pada menjadi keniscayaan bagi berbagai industri dalam menghadapi berbagai isu lingkungan dan kesadaran konsumen pada saat ini. Industri furniture kayu di Indonesia memiliki berbagai faktor yang memengaruhi dalam penerapan GSCM. Dari pembahasan yang dilakukan didapatkan 
bahwa yang dominan memengaruhi penerapan GSCM pada industri furniture kayu di Indonesia adalah perilaku konsumen, dukungan dari manajemen puncak, dan strategi organisasi. Untuk penelitian selanjutnya dapat menambahkan kriteria-kriteria yang belum teridentifikasi dalam makalah ini. Penelitian selanjutnya dapat menggunakan tools Multi Criteria Decision Making (MCDM) yang lain dalam menghitung kriteria yang paling dominan.

\section{Referensi}

[1] A. Kusumawardhani and G. McCarthy, "Innovation in small and medium-sized wood-furniture firms in Central Java, Indonesia," in Proceedings of the International Conference on Managing the Asian Century, 2013, pp. 471-480.

[2] J. Ratnasingam and F. Ioras, "The sustainability of the Asian wooden furniture industry," Holz als Roh-und Werkstoff, vol. 61, pp. 233-237, 2003.

[3] A. Priyono, "Determinant Factors of Indonesia Furniture Export to European Union," PhD Thesis, Faculty of Economics Universitas Indonesia, Jakarta, 2009.

[4] A. S. Salam, "SVLK; Salah Satu Jenis EcoLabeluntuk Mengontrol Pergerakan Kayu pada Industri Furnitur di Jepara," 2013.

[5] R. H. Sees, "Guide to Supply Chain Management: How Getting It Right Boosts Corporate Performance (The Economist) by David Jacoby," Transportation Journal, vol. 52, pp. 522-524, 2013.

[6] D. Blanchard, Supply chain management best practices: John Wiley \& Sons, 2010.

[7] J. T. Mentzer, W. DeWitt, J. S. Keebler, S. Min, N. W. Nix, C. D. Smith, et al., "Defining supply chain management," Journal of Business logistics, vol. 22, pp. 1$25,2001$.

[8] D. M. Lambert, Supply chain management: processes, partnerships, performance: Supply Chain Management Inst, 2008.

[9] T. Hines, Supply Chain Strategies: Customer-driven and customer-focused: Routledge, 2004.

[10] A. A. Hervani, M. M. Helms, and J. Sarkis, "Performance measurement for green supply chain management," Benchmarking: An international journal, vol. 12, pp. 330-353, 2005.

[11] Q. Zhu and J. Sarkis, "Relationships between operational practices and performance among early adopters of green supply chain management practices in Chinese manufacturing enterprises," Journal of operations management, vol. 22, pp. 265-289, 2004.

[12] V. Jain and S. Sharma, "Drivers affecting the green supply chain management adaptation: a review," IUP Journal of Operations Management, vol. 13, p. 54, 2014.

[13] C. Ninlawan, P. Seksan, K. Tossapol, and W. Pilada, "The implementation of green supply chain management practices in electronics industry," in Proceedings of the international multiconference of engineers and computer scientists, 2010, pp. 17-19.

[14] R.-J. Lin, R.-H. Chen, and T.-H. Nguyen, "Green supply chain management performance in automobile manufacturing industry under uncertainty," ProcediaSocial and Behavioral Sciences, vol. 25, pp. 233-245, 2011.

[15] R. A. Hadiguna, H. S. Jaafar, and S. Mohamad, "A model for vendor managed inventory by applying the economic order quantity with fuzzy demand," International Journal of Enterprise Network Management, vol. 4, pp. 354-366, 2011. 
[16] M. Mustafid, "Sistem Informasi Untuk Supply Chain Berkelanjutan Berbasis Pengetahuan," JSINBIS (Jurnal Sistem Informasi Bisnis), vol. 5, pp. 109-118, 2015.

[17] T. L. Saaty, "How to make a decision: the analytic hierarchy process," European journal of operational research, vol. 48, pp. 9-26, 1990.

[18] H. Saputra and P. Fithri, "Perancangan Model Pengukuran Kinerja Green Supply Chain Pulp dan Kertas," Jurnal Optimasi Sistem Industri, vol. 11, pp. 193-202, 2012.

[19] S. Suryaningrat, Y. Firdusah, and E. Novita, "Analisis Finansial Penerapan Konsep Green Supply Chain Manajemen Pada Pengolahan Kopi."

[20] M. A. A. Rehman and R. L. Shrivastava, "An innovative approach to evaluate green supply chain management (GSCM) drivers by using interpretive structural modeling (ISM)," International Journal of Innovation and Technology Management, vol. 8, pp. 315-336, 2011.

[21] S. Routroy, "Antecedents and drivers for green supply chain management implementation in manufacturing environment," ICFAI Journal of Supply Chain Management, vol. 6, pp. 20-35, 2009.

[22] H. Walker, L. Di Sisto, and D. McBain, "Drivers and barriers to environmental supply chain management practices: Lessons from the public and private sectors," Journal of purchasing and supply management, vol. 14, pp. 69-85, 2008.

[23] Z. J. H. Tarigan, "Dukungan Manajemen Puncak terhadap Strategic Purchasing dalam Berkomunikasi dan Berkolaborasi dengan Supplier untuk Meningkatkan Kinerja Perusahaan," Jurnal Manajemen dan Kewirausahaan, vol. 11, pp. pp. 126-133, 2010.

[24] S. Javed, "Impact of Top Management Commitment on Quality Management," International Journal of Scientific and Research Publications, vol. 5, 2015.

[25] R. Young and E. Jordan, "Top management support: Mantra or necessity?," International journal of project management, vol. 26, pp. 713-725, 2008.

[26] E. G. Olson, "Creating an enterprise-level "green" strategy," Journal of business strategy, vol. 29, pp. 22-30, 2008.

[27] S. M. Masoumik, S. H. Abdul-Rashid, and E. Udoncy Olugu, "Gaining competitive advantage through strategic green supply chain management: From a literature review towards a conceptual model," International Journal of Supply Chain Management, vol. 3, 2014.

[28] A. M. Deif, "A system model for green manufacturing," Journal of Cleaner Production, vol. 19, pp. 1553-1559, 2011.

[29] S. Hartini and U. Ciptomulyono, "The relationship between lean and sustainable manufacturing on performance: literature review," Procedia Manufacturing, vol. 4, pp. 38-45, 2015.

[30] H. Onsrud and R. Simon, "The social, business, and Policy environment for Green Manufacturing," in Green Manufacturing, ed: Springer, 2013, pp. 25-47.

[31] M. Bhardwaj, Neelam, N., "The Advantages and Disadvantages of Green Technology," Journal of Basic and Applied Engineering Research, pp. 1957-1960, 2015.

[32] V. K. Mittal and K. S. Sangwan, "Prioritizing drivers for green manufacturing: environmental, social and economic perspectives," Procedia CIRP, vol. 15, pp. 135-140, 2014.

[33] Y. Joshi and Z. Rahman, "Factors affecting green purchase behaviour and future research directions," International Strategic Management Review, vol. 3, pp. 128$143,2015$. 
[34] M. Mutingi, "The impact of reverse logistics in green supply chain management: a system dynamics analysis," International Journal of Industrial and Systems Engineering, vol. 17, pp. 186-201, 2014.

[35] M. S. Satav and V. Yakkundi, "Green Manufacturing Initiative by Industries and Government Regulatory Authorities in Indian Iron and Steel Sector," IRACSTEngineering Science and Technology: An International Journal (ESTIJ), ISSN, pp. 2250-3498, 2014. 